\title{
Q.
QNEEN'S
UNIVERSITY
BELFAST
}

\section{Effect of elemental sulphur on uptake of cadmium, zinc, and sulphur by oilseed rape growing in soil contaminated with zinc and cadmium}

Cui, Y. S., Wang, Q. R., \& Christie, P. (2004). Effect of elemental sulphur on uptake of cadmium, zinc, and sulphur by oilseed rape growing in soil contaminated with zinc and cadmium. Communications in Soil Science and Plant Analysis, 35(19-20), 2905-2916. https://doi.org/10.1081/LCSS-200036494

Published in:

Communications in Soil Science and Plant Analysis

Queen's University Belfast - Research Portal:

Link to publication record in Queen's University Belfast Research Portal

\section{General rights}

Copyright for the publications made accessible via the Queen's University Belfast Research Portal is retained by the author(s) and / or other copyright owners and it is a condition of accessing these publications that users recognise and abide by the legal requirements associated with these rights.

Take down policy

The Research Portal is Queen's institutional repository that provides access to Queen's research output. Every effort has been made to ensure that content in the Research Portal does not infringe any person's rights, or applicable UK laws. If you discover content in the Research Portal that you believe breaches copyright or violates any law, please contact openaccess@qub.ac.uk. 


\title{
Effect of Elemental Sulphur on Uptake of Cadmium, Zinc, and Sulphur by Oilseed Rape Growing in Soil Contaminated with Zinc and Cadmium
}

\author{
Yanshan Cui, ${ }^{1}$ Qingren Wang, ${ }^{2, *}$ and Peter Christie ${ }^{3}$ \\ ${ }^{1}$ Graduate Student, Chinese Academy of Sciences, Beijing, China \\ ${ }^{2}$ Research Center for Eco-Environmental Sciences, \\ Chinese Academy of Sciences, Beijing, China \\ ${ }^{3}$ Agricultural and Environmental Science Department, \\ Queen's University Belfast, Newforge Lane, Belfast, UK
}

\begin{abstract}
A pot experiment was conducted to study the influence of elemental sulphur $\left(\mathrm{S}^{0}\right)$ on cadmium $(\mathrm{Cd})$, zinc $(\mathrm{Zn})$, and sulphur $(\mathrm{S})$ uptake by oilseed rape (Brassica napus L.) grown in a calcareous soil contaminated with either $\mathrm{Cd}$ or $\mathrm{Zn}$ or with both $\mathrm{Zn}$ and $\mathrm{Cd}$ together. Elemental sulphur was applied at two rates $(0$ and $200 \mathrm{mmol}), \mathrm{Cd}$ at two rates $(0$ and $20 \mathrm{mg})$, and $\mathrm{Zn}$ at three rates $(0$, 20, and $200 \mathrm{mg}$ ) $\mathrm{kg}^{-1}$ soil. Cadmium (as $\mathrm{CdCl}_{2}$ ) and $\mathrm{Zn}$ (as $\mathrm{ZnCl}_{2}$ )
\end{abstract}

*Correspondence: Qingren Wang, Tropical Research and Education Center, University of Florida, 18905 SW 280th Street, Homestead, FL 33031, USA; Fax: 305-246-7003; E-mail: qrwang@mail.ifas.ufl.edu.

DOI: $10.1081 /$ LCSS-200036494

Copyright @ 2004 by Marcel Dekker, Inc.
0010-3624 (Print); 1532-2416 (Online) www.dekker.com 
were added in solution to soil prior to planting. After 10 days, $\mathrm{S}^{0}$ and fertilizer were thoroughly mixed and added to the soil. Plants were harvested after growing for 40 days in a greenhouse. Soil $\mathrm{pH}$ and shoot dry weight decreased significantly in response to $\mathrm{S}^{0}$ application. Addition of $\mathrm{Zn}$ and $\mathrm{Cd}$ did not influence plant growth without $\mathrm{S}^{0}$ supply. Shoot concentrations of $\mathrm{Zn}$ and $\mathrm{Cd}$ increased significantly with $\mathrm{Zn}$ and $\mathrm{Cd}$ addition as well as $\mathrm{S}^{0}$ supply. Cadmium addition did not lead to any change in shoot $\mathrm{Zn}$ concentration. Shoot $\mathrm{Cd}$ concentration decreased in the $200 \mathrm{mg} \mathrm{kg}^{-1} \mathrm{Zn}$ addition treatment compared with the control but remained unchanged in all $\mathrm{Zn}$ treatments when $S^{0}$ was applied. Shoot $S$ concentration increased with application of $\mathrm{S}^{0}, \mathrm{Zn}$, and $\mathrm{Cd}$. Shoot $\mathrm{Zn}$ and $\mathrm{Cd}$ uptake by oilseed rape increased significantly with the $\mathrm{Zn}$ and $\mathrm{Cd}$ addition. However, shoot $\mathrm{Zn}$ removal did not increase significantly, and $\mathrm{Cd}$ removal decreased when $\mathrm{S}$ was applied. In conclusion, $\mathrm{S}^{0}$ acidified the soil and increased shoot concentrations of $\mathrm{Zn}$ and $\mathrm{Cd}$, but its depressive effect on shoot biomass was so pronounced that it would not enhance phytoextraction of $\mathrm{Cd}$ or $\mathrm{Zn}$ from this soil by oilseed rape.

Key Words: Bioavailability; Heavy metals; Phytoremediation; Shoot uptake; Soil acidification.

\section{INTRODUCTION}

Soils can be contaminated with $\mathrm{Cd}$ and $\mathrm{Zn}$ from sewage sludge or urban composts, fertilizers, emissions from municipal-waste incinerators, residues from metal smelting and refining, and other human activities. Cadmium is a nonessential element for plants and is generally considered as a toxic contaminant in food for humans and animal feeds ${ }^{[1]}$ Zinc is an essential nutrient for plant growth, but concentrations of $\mathrm{Zn}$ in contaminated soils have frequently been found to exceed plant requirements and may cause phytotoxicity. ${ }^{[2]}$ Excessive accumulation of $\mathrm{Cd}$ and $\mathrm{Zn}$ in soils must therefore be avoided or remediated to avoid their transfer to plants and food chains. ${ }^{[3]}$

There is currently no suitable method for removal of $\mathrm{Cd}$ and $\mathrm{Zn}$ from soils in the short term while preserving soil properties. Phytoextraction is one option for remediation of metal-contaminated soils, and the bioavailability of heavy metals is an important factor in the process of phytoextraction. ${ }^{[2-4]}$

There are many soil properties that influence the bioavailability of soil $\mathrm{Cd}$ and $\mathrm{Zn}$, including $\mathrm{pH}$, types of minerals present, types and amounts of anions in the soil solution, organic-matter content, and $\mathrm{Zn}$ or 
Cd carriers. ${ }^{[5-7]}$ Soil $\mathrm{pH}$ is often one of the most important properties influencing the mobility and bioavailability of $\mathrm{Cd}$ and $\mathrm{Zn}$ in soils. ${ }^{[6,7]} \mathrm{A}$ decrease in soil $\mathrm{pH}$ can be achieved by application of mineral or organic acids or acidifying fertilizers such as ammonium chloride ${ }^{[8-10]}$ However, these methods have limitations due to their negative effects on soil's chemical, physical, and biological properties. The use of $S^{0}$ has therefore been suggested for alleviation of these constraints and for soil acidification to increase the solubility of metals in contaminated soils. ${ }^{[1-13]}$ However, there have been few studies that have evaluated the feasibility of this method as a tool for enhancement of metal uptake by plants growing in soils with different levels of $\mathrm{Cd}$ and $\mathrm{Zn}$ in addition to plant uptake of $\mathrm{S}$. The objectives of our study were to investigate the tissue concentrations and uptake rates of $\mathrm{Cd}, \mathrm{Zn}$, and $\mathrm{S}$ in oilseed rape that was grown in soil experimentally contaminated with different levels of $\mathrm{Cd}$ and $\mathrm{Zn}$ with and without application of $\mathrm{S}^{0}$.

\section{MATERIALS AND METHODS}

\section{Soil}

Soil was collected from the top $20 \mathrm{~cm}$ of the profile in a field in Qinghe, Beijing, China. The soil was air-dried, ground, passed through a 2-mm sieve and had the following physico-chemical properties prior to the experiment: $\mathrm{pH}$ (in $0.01 \mathrm{M} \mathrm{CaCl}_{2}$ ) 7.25, organic-matter content $12 \mathrm{~g}$, total $\mathrm{Zn} 68 \mathrm{mg}$, and total $\mathrm{Cd} 0.8 \mathrm{mg} \mathrm{kg}^{-1}$.

\section{Plant Cultivation}

Oilseed rape (Brassica napus L. cv. Siyueman) seeds were sown at a rate of 6 pot $^{-1}$ and thinned to three seedlings in each pot 1 week after germination. The experiment was carried out in a glasshouse with a $14 \mathrm{~h}$ $\left(28^{\circ} \mathrm{C}\right) / 10 \mathrm{~h}\left(15^{\circ} \mathrm{C}\right)$ day/night cycle. Soil-moisture content was adjusted regularly by weight to about $60 \%$ of water-holding capacity and the plants were harvested after 40 days of growth.

\section{Experimental Design and Treatments}

The experimental treatments consisted of $\mathrm{S}^{0}$ applied at two rates ( 0 and $\left.200 \mathrm{mmol} \mathrm{kg}^{-1}\right), \mathrm{Cd}$ at two rates $\left(0\right.$ and $20 \mathrm{mg} \mathrm{kg}^{-1}$ soil), and $\mathrm{Zn}$ at 
three rates $\left(0,20,200 \mathrm{mg} \mathrm{kg}^{-1}\right.$ soil) in a multifactorial design. Thus there were 12 treatments in triplicate, giving a total of 36 pots. Fertilizer was applied at rates of $120 \mathrm{mg} \mathrm{N}$ (as $\mathrm{NH}_{4} \mathrm{NO}_{3}$ ), $80 \mathrm{mg} \mathrm{P}$ (as $\mathrm{KH}_{2} \mathrm{PO}_{4}$ ), and $120 \mathrm{mg} \mathrm{K} \mathrm{kg}^{-1}$ (as $\mathrm{KCl}$ and $\mathrm{KH}_{2} \mathrm{PO}_{4}$ ). Cadmium (as $\mathrm{CdCl}_{2}$ ) and $\mathrm{Zn}$ (as $\mathrm{ZnCl}_{2}$ ) were added in solution to portions of soil prior to potting, and 10 days later, elemental sulphur $\left(\mathrm{S}^{0}\right)$ and the fertilizers were thoroughly mixed and added to the soil. Each pot contained $1 \mathrm{~kg}$ of soil, which was allowed to equilibrate for a period of 14 days in the glasshouse before the seeds were sown.

\section{Soil and Plant Analysis}

Soil samples were taken before the experiment and after the plants were harvested. Soil $\mathrm{pH}$ was measured on subsamples using a 1:2.5 soil:0.01 $\mathrm{M} \mathrm{CaCl} 2$ ratio using a $\mathrm{pH}$ meter. Total $\mathrm{Zn}$ and $\mathrm{Cd}$ were determined using aliquots of air-dried soil ground to $<0.25 \mathrm{~mm}$ and digested with a mixture of concentrated $\mathrm{HNO}_{3}: \mathrm{HClO}_{4}: \mathrm{HF}(3: 1: 1 \mathrm{v} / \mathrm{v} / \mathrm{v})$, and total $\mathrm{Zn}$ and $\mathrm{Cd}$ were analyzed by inductively coupled plasma optical emission spectroscopy (ICP-OES) using a Perkin-Elmer Optima 2000 spectrophotometer. Plant shoots were harvested and rinsed with deionized water, oven-dried at $70^{\circ} \mathrm{C}$ for $48 \mathrm{~h}$, ground with an agate mill, digested with a mixture of concentrated $\mathrm{HNO}_{3}: \mathrm{HClO}_{4}(3: 1 \mathrm{v} / \mathrm{v})$; total $\mathrm{Zn}, \mathrm{Cd}$, and $\mathrm{S}$ were analyzed by ICP-OES.

\section{Statistical Analysis}

Data were subjected to three-way ANOVA using the SAS package (version 8.1, SAS, Inc., Cary, NC, USA).

\section{RESULTS AND DISCUSSION}

\section{Soil pH}

Soil $\mathrm{pH}$ decreased significantly in all $\mathrm{S}^{0}$ application treatments with the largest decrease occurring at a combined addition of $200 \mathrm{mmol} \mathrm{S}$, $20 \mathrm{mg} \mathrm{Zn}$, and $20 \mathrm{mg} \mathrm{Cd} \mathrm{kg}^{-1}$. Furthermore, the acidifying effect of $\mathrm{S}^{0}$ on the soil was more pronounced when $\mathrm{Cd}$ or $\mathrm{Zn}$ was applied (Table 1). There were significant interactions between $\mathrm{S}^{0}$ and $\mathrm{Zn}$ and between $\mathrm{S}^{0}$ and $\mathrm{Cd}$, but not between $\mathrm{Zn}$ and $\mathrm{Cd}$. The soil acidifying effect of $\mathrm{S}^{0}$ may 
Table 1. Changes in soil $\mathrm{pH}$ after plant harvest in soil amended with $\mathrm{S}^{0}, \mathrm{Cd}$, and $\mathrm{Zn}$.

\begin{tabular}{ccccc}
\hline & \multicolumn{4}{c}{$\mathrm{S}^{0}$ rate $\left(\mathrm{mmol} \mathrm{kg}^{-1}\right)$} \\
\cline { 2 - 5 } & \multicolumn{4}{c}{000} \\
\cline { 2 - 5 } & \multicolumn{4}{c}{ Cd rate $\left(\mathrm{mg} \mathrm{kg}^{-1}\right)$} \\
\cline { 2 - 5 } Zn rate $\left(\mathrm{mg} \mathrm{kg}^{-1}\right)$ & 0 & 20 & 0 & 20 \\
\hline 0 & 7.32 & 7.37 & 6.39 & 5.72 \\
20 & 7.38 & 7.25 & 5.53 & 5.06 \\
200 & 7.34 & 7.26 & 5.41 & 5.13 \\
\hline
\end{tabular}

Significance $^{\mathrm{a}}$

$\mathrm{S}^{0}$ rate

$\mathrm{Zn}$ rate

Cd rate

$\mathrm{S}^{0} \times \mathrm{Zn}$

$\mathrm{S}^{0} \times \mathrm{Cd}$

$\mathrm{Zn} \times \mathrm{Cd}$

$\mathrm{S}^{0} \times \mathrm{Zn} \times \mathrm{Cd}$

b

b

b

b

c

ns

ns

${ }^{\mathrm{a}} \mathrm{By}$ analysis of variance.

${ }^{\mathrm{b}} p<0.001$.

${ }^{\mathrm{c}} p<0.01$.

$\mathrm{ns}=$ not significant.

be explained by the activities of certain groups of acidophilic soil bacteria, particularly the genus Thiobacillus, which can metabolize $\mathrm{S}^{0}$ in the presence of $\mathrm{O}_{2}$ and generate $\mathrm{H}^{+}$and $\mathrm{SO}_{4}^{2-}$, leading to soil acidification. ${ }^{[11-14]}$

\section{Plant Growth}

Shoot dry weights decreased with $\mathrm{S}^{0}$ application (Table 2). Addition of $\mathrm{Zn}$ or $\mathrm{Cd}$ did not influence the shoot biomass when $\mathrm{S}^{0}$ was not applied. The significant interaction between $\mathrm{S}^{0}$ and $\mathrm{Zn}$ indicates the smaller shoot biomass at the low $\mathrm{Zn}$ application rate in the absence of added $\mathrm{S}$.

Kayser et al. ${ }^{[1]}$ reported that shoot weight in some plants did not change significantly with $\mathrm{S}^{0}$ application. However, in the present study, acidification of the calcareous soil may have depressed the growth of the oilseed rape. 
Table 2. Shoot biomass of oilseed rape $\left(\mathrm{g} \mathrm{pot}^{-1}\right)$ grown in soil amended with $\mathrm{S}^{0}$, $\mathrm{Cd}$, and $\mathrm{Zn}$.

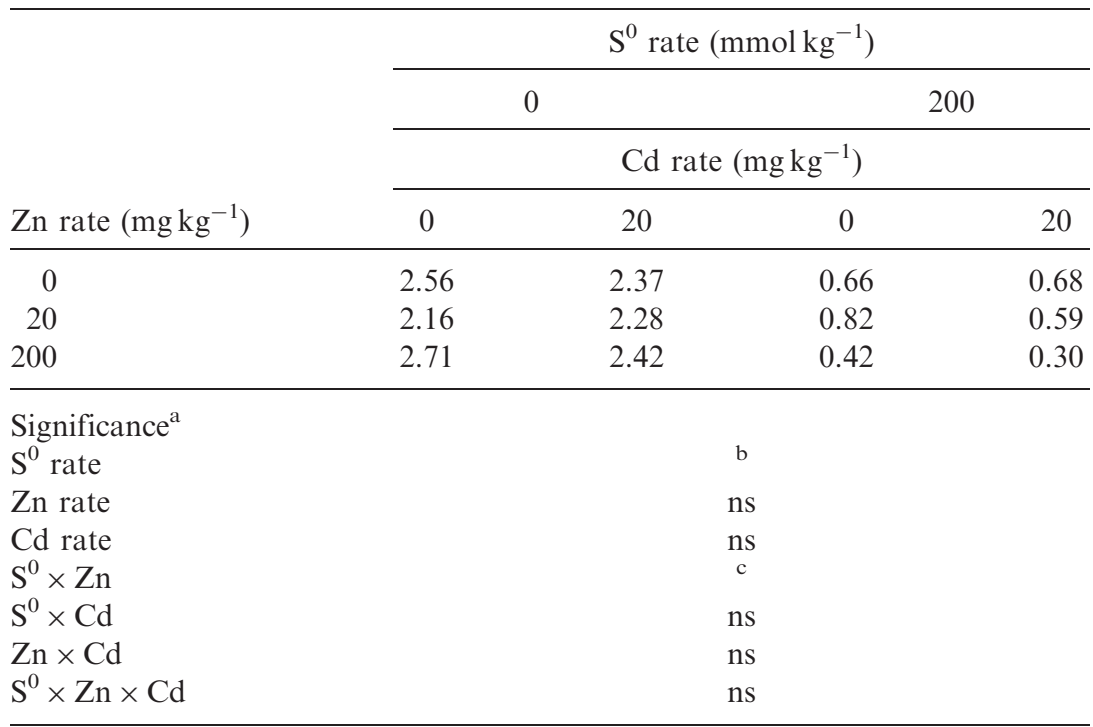

\footnotetext{
${ }^{\mathrm{a}} \mathrm{By}$ analysis of variance.

${ }^{\mathrm{b}} p<0.001$.

${ }^{\mathrm{c}} p<0.01$.

ns $=$ not significant.
}

\section{Shoot Concentrations of Zinc and Cadmium}

The concentration of $\mathrm{Zn}$ in oilseed rape shoots increased with increasing $\mathrm{Zn}$ addition and with $\mathrm{S}^{0}$ application but was unaffected by added $\mathrm{Cd}$ (Table 3 ). Shoot $\mathrm{Cd}$ increased significantly with $\mathrm{Cd}$ addition and $\mathrm{S}^{0}$ supply but decreased when $200 \mathrm{mg} \mathrm{kg}^{-1} \mathrm{Zn}$ was applied in the absence of added $S^{0}$ compared with the control. However, when $S^{0}$ was applied, the shoot concentration of $\mathrm{Cd}$ was unaffected by both application rates of $\mathrm{Zn}$.

Other studies have also found that increasing concentrations of heavy metals in soils led to higher accumulation of heavy metals in plant tissues. ${ }^{[15,16]}$ Without added $\mathrm{S}^{0}$, increasing $\mathrm{Zn}$ application rate led to a decrease in shoot $\mathrm{Cd}$ concentration, a result that agrees with other studies that have indicated that $\mathrm{Zn}$ application can lower $\mathrm{Cd}$ concentrations in some plant species. ${ }^{[17,18]}$ In contrast, as far as we know, there is no published information on the effects of increasing levels of $\mathrm{Zn}$ application on $\mathrm{Cd}$ concentrations in plants with $\mathrm{S}^{0}$ application to the soil. In the 


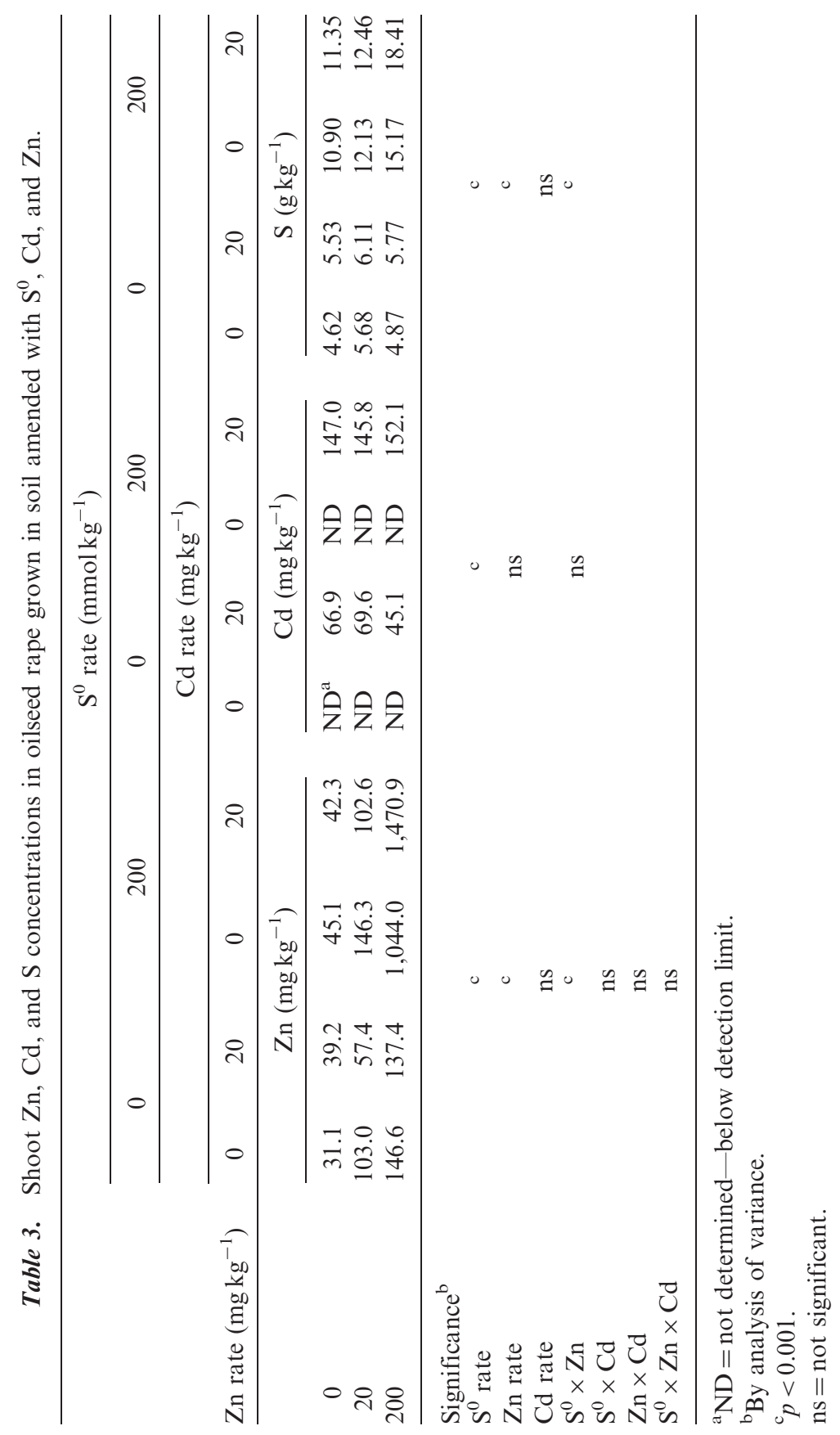


present study, the shoot $\mathrm{Cd}$ concentration did not change significantly under different levels of $\mathrm{Zn}$ application with added $\mathrm{S}^{0}$. Soil application of $\mathrm{S}^{0}$ led to increased shoot concentrations of $\mathrm{Cd}$ and $\mathrm{Zn}$. This may have been due partly to an increase in the solubility of soil $\mathrm{Zn}$ and $\mathrm{Cd}$ and an increase in their bioavailability due to soil acidification by S. McLaughlin et al. ${ }^{[16]}$ reported that increasing $\mathrm{SO}_{4}^{2-}$ in soil increased shoot $\mathrm{Cd}$ concentrations. A similar increase in soil $\mathrm{SO}_{4}^{2-}$ may have resulted from application of $\mathrm{S}^{0}$ in the present experiment. Addition of $\mathrm{S}^{0}$ to contaminated soils has been reported to increase concentrations of heavy metals and $\mathrm{S}$ in plants. ${ }^{[11,13]}$ In the present study, $\mathrm{S}$ application increased shoot concentrations of $\mathrm{Zn}$ and $\mathrm{Cd}$ in all treatments spiked with $\mathrm{Zn}$ or $\mathrm{Cd}$, and this agrees well with the results of Kayser et al. ${ }^{[11]}$ and Tichý et al. ${ }^{[13]}$ The other factor that can affect shoot concentrations of the metals is shoot biomass, this can be taken into account by calculating the quantities of the metals taken up by the shoots.

\section{Shoot Sulphur Concentrations}

As expected, shoot $\mathrm{S}$ concentrations responded to $\mathrm{S}^{0}$ application, probably due to increased uptake of $\mathrm{SO}_{4}^{2-}$ from the soil and also increased with $\mathrm{Zn}$ and $\mathrm{Cd}$ addition (Table 3). Using hydroponic culture, Coolong and Randle ${ }^{[1]}$ found that total $\mathrm{S}$ in field mustard (Brassica rapa) shoots was higher with $\mathrm{Zn}$ supply than in controls without $\mathrm{Zn}$ supply when the plants were exposed to $\mathrm{Zn}$ levels ranging from 1 to $25 \mathrm{mg} \mathrm{L}^{-1}$. In the present study, the shoot concentrations of $\mathrm{S}$ increased significantly with $\mathrm{Zn}$ addition whether or not $\mathrm{S}^{0}$ was applied. This result conflicts with Kumar and Singh ${ }^{[15]}$ who found that total $S$ in soybean decreased significantly with increasing $\mathrm{Zn}$ levels from 5 to $10 \mathrm{mg} \mathrm{kg}^{-1}$. The effects of $\mathrm{Zn}$ or Cd supply on total $\mathrm{S}$ in plants may depend on numerous factors, such as $\mathrm{Zn}, \mathrm{Cd}$, S, and fertilizer sources, crop-growth conditions, and plant species.

\section{Shoot Uptake of Zinc and Cadmium}

Shoot $\mathrm{Zn}$ and $\mathrm{Cd}$ uptake increased significantly with $\mathrm{Zn}$ and $\mathrm{Cd}$ addition (Table 4). However, $\mathrm{S}^{0}$ application had no effect on shoot $\mathrm{Zn}$ uptake, and it depressed shoot $\mathrm{Cd}$ uptake despite the increases in shoot concentrations of the metals reported above. The drastic reduction in shoot biomass produced by $\mathrm{S}^{0}$ application has therefore prevented the $\mathrm{S}$ treatment from increasing the rate of removal of $\mathrm{Cd}$ or $\mathrm{Zn}$ from the soil by phytoextraction using oilseed rape. Other studies ${ }^{[19]}$ in which both 


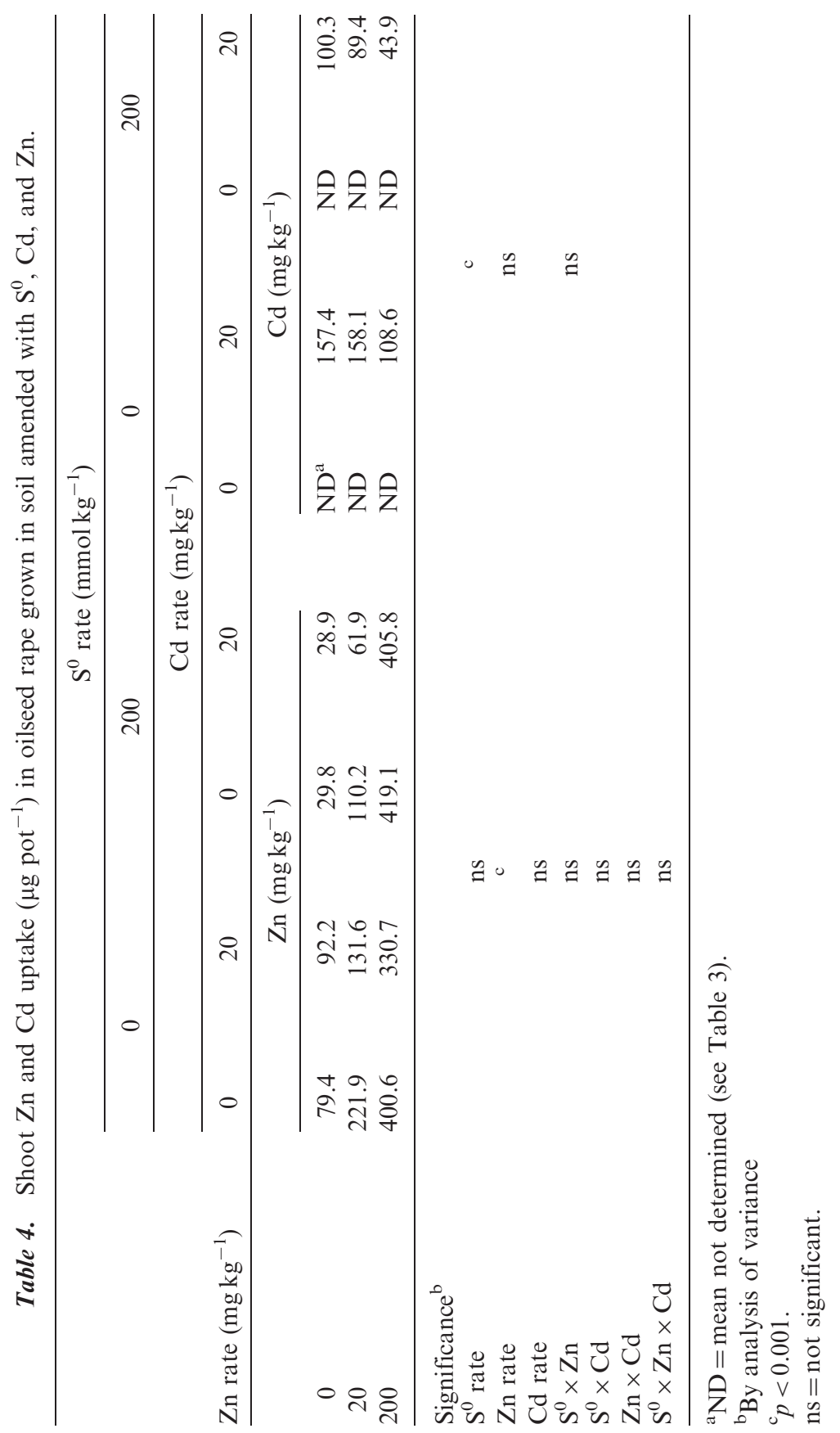


EDTA and $\mathrm{S}$ have been applied to the soil have indicated that the EDTA was more effective than $\mathrm{S}$ in mobilizing lead $(\mathrm{Pb})$ and $\mathrm{Zn}$ for extraction by Indian mustard and wheat, but $\mathrm{S}$ made a useful contribution to metal removal by acting synergistically with the EDTA. Thus it seems that $S$ application on its own may not be effective, but perhaps it can be used in combination with a chelating agent to increase soil-metal bioavailability for phytoextraction.

\section{CONCLUSIONS}

Elemental $\mathrm{S}$ decreased soil $\mathrm{pH}$ and increased shoot concentrations of $\mathrm{Zn}$ and $\mathrm{Cd}$ of oilseed rape but did not significantly enhance the uptake of the metals. Shoot concentrations of S increased with increasing supply of elemental S, Cd, and $\mathrm{Zn}$. The results indicate that adding elemental $\mathrm{S}$ to soil can increase $\mathrm{Zn}$ and $\mathrm{Cd}$ concentrations, but shoot uptake of the metals may not increase because of a marked depression in shoot biomass. Application of $\mathrm{S}^{0}$ alone may therefore be ineffective for enhancement of phytoremediation of calcareous soils by oilseed rape.

\section{ACKNOWLEDGMENTS}

We thank the National Natural Science Foundation of China (Project 40171087) and the Chinese Academy of Sciences Knowledge Innovation Project (KZCX2-401-01) for their generous financial support.

\section{REFERENCES}

1. Coolong, T.W.; Randle, W.M. Zinc concentration in hydroponic solution culture influences zinc and sulfur accumulation in Brassica rapa L. J. Plant Nutr. 2003, 26, 949-959.

2. Lock, K.; Janssen, C.R. Ecotoxicity of zinc in spiked artificial soils versus contaminated field soils. Environ. Sci. Technol. 2001, 35, 4295-4300.

3. Schwartz, C.; Echevarria, G.; Morel, J.L. Phytoextraction of cadmium with Thlaspi caerulescens. Plant Soil 2003, 249, 27-35.

4. Bunzl, K.; Trautmannsheimer, M.; Schramel, P.; Reifenhauser, W. Availability of arsenic, copper, lead, thallium and zinc to various vegetables grown in slag-contaminated soils. J. Environ. Qual. 2001, 30, 934-939. 
5. Basta, N.T.; Tabatabai, M.A. Effect of cropping systems on adsorption of metals by soils. II. . Effect of pH. Soil Sci. 1992, 153, 195-204.

6. Harter, R.D. Effect of soil $\mathrm{pH}$ on adsorption of lead, copper, zinc, and nickel. Soil Sci. Soc. Am. J. 1983, 47, 47-51.

7. Ziper, C.; Komarneni, S.; Baker, D.E. Specific cadmium sorption in relation to the crystal chemistry of clay minerals. Soil Sci. Soc. Am. J. 1988, 52, 49-53.

8. Huang, J.W.W.; Chen, J.J.; Berti, W.R.; Cunningham, S.D. Phytoremediation of lead-contaminated soils: role of synthetic chelates in lead phytoextraction. Environ. Sci. Technol. 1997, 31, 800-805.

9. Salt, D.E.; Blaylock, M.; Kumar, N.P.B.A.; Dushenkov, V.; Ensley, B.D.; Chet, I.; Raskin, I. Phytoremediation: a novel strategy for removal of toxic metals from the environment using plants. Biotechnology 1995, 13, 468-474.

10. Wasay, S.A.; Barrington, S.F.; Tokunaga, S. Remediation of soils polluted by heavy metals using salts of organic acids and chelating agents. Environ. Technol. 1998, 19, 369-379.

11. Kayser, A.; Wenger, K.; Keller, A.; Attinger, W.; Felix, H.R.; Gupta, S.K.; Schulin, R. Enhancement of phytoextraction of Zn, $\mathrm{Cd}$, and $\mathrm{Cu}$ from calcareous soil: the use of NTA and sulfur amendments. Environ. Sci. Technol. 2000, 34, 1778-1783.

12. Seidel, H.; Ondruschka, J.; Morgenstern, P.; Stottmeister, U. Bioleaching of heavy metals from contaminated aquatic sediments using indigenous sulfur-oxidizing bacteria: a feasibility study. Water Sci. Technol. 1998, 37, 387-394.

13. Tichý, R.; Fajtl, J.; Kuzel, S.; Kolar, L. Use of elemental sulphur to enhance cadmium solubilization and its vegetative removal from contaminated soil. Nutr. Cycl. Agroecosyst. 1997, 46, 249-255.

14. Lee, A.; Boswell, C.C.; Watkinson, J.H. Effect of particle size on the oxidation of elemental sulfur, thiobacilli numbers, soil sulfate and its availability to pasture. N.Z. J. Agric. Res. 1988, 31, 179-186.

15. Kumar, V.; Singh, M. Sulfur and zinc interactions in relation to yield, uptake, and utilization of sulfur in soybean. Soil Sci. 1980, $130,19-25$.

16. McLaughlin, M.J.; Lambrechts, R.M.; Smolders, E.; Smart, M.K. Effects of sulfate on cadmium uptake by Swiss chard. II. Effects due to sulfate addition to soil. Plant Soil 1998, 202, 217-222.

17. Grant, C.A.; Bailey, L.D. Effects of phosphorus and zinc fertiliser management effects on cadmium accumulation in flaxseed. J. Sci. Food Agric. 1997, 73, 307-314. 
18. Oliver, D.P.; Hannam, R.; Tiller, K.G.; Wilhelm, N.S.; Merry, R.H.; Cozens, G.D. The effects of zinc fertilization on cadmium concentration in wheat grain. J. Environ. Qual. 1994, 23, 705-711.

19. Cui, Y.S.; Wang, Q.R.; Dong, Y.T.; Li, H.F.; Christie, P. Enhanced uptake of soil $\mathrm{Pb}$ and $\mathrm{Zn}$ by Indian mustard and winter wheat following combined soil application of elemental sulphur and EDTA. Plant Soil 2004, 261, 181-188. 